\title{
3-Oxo-5-Alpha-Steroid 4-Dehydrogenase 2
}

National Cancer Institute

\section{Source}

National Cancer Institute. 3-Oxo-5-Alpha-Steroid 4-Dehydrogenase 2. NCI Thesaurus. Code $\mathrm{C17190.}$

3-oxo-5-alpha-steroid 4-dehydrogenase 2 ( $254 \mathrm{aa}, \sim 28 \mathrm{kDa}$ ) is encoded by the human SRD5A2 gene. This protein plays a role in sexual differentiation and androgen metabolism. 